\title{
Environmental anomalies, energetic reserves and fatty acid modifications in oysters coincide with an exceptional mortality event
}

\author{
Fabrice Pernet ${ }^{1, *}$, Jean Barret ${ }^{1}$, Claire Marty ${ }^{2}$, Jeanne Moal ${ }^{3}$, Patrik Le Gall ${ }^{1}$, \\ Pierre Boudry ${ }^{3}$ \\ ${ }^{1}$ Laboratoire Environnement Ressources du Languedoc Roussillon, Ifremer, Bd. Jean Monnet, 34200 Sète, France \\ ${ }^{2}$ Cépralmar, Stratégie Concept Bât. 1, 1300 Av. Albert Einstein, 34000 Montpellier, France \\ ${ }^{3}$ UMR M100 Physiologie et Ecophysiologie des Mollusques Marins, Ifremer, Technopole de Brest-Iroise, \\ 29280 Plouzané, France
}

\begin{abstract}
Mortality of oysters Crassostrea gigas occurred along the coasts of France during summer 2008, causing a serious crisis in French oyster production. During spring to summer 2008, 5 groups of 1-yr old oysters of different origins and ploidy levels deployed in the Thau lagoon (France) were sampled for biometrical and biochemical analyses; environmental parameters were monitored in the same area. Mortality occurred in 2 episodes: 13 May to 10 June and 24 June to 9 July. Wild-collected oysters showed mortality sooner than other groups but total overall mortality was $85 \%$ in all groups. Mortality occurred when seawater temperature was $>19^{\circ} \mathrm{C}$ during the reproductive season when energetic reserves of oysters were at their lowest. Energy reserve levels and mortality in oysters seemed to be independent of reproductive effort, and most likely reflected an unusual deficit in phytoplankton. The level of bacterial fatty acids in oysters increased markedly before the second mortality event, probably indicating an enhancement of the microbial loop or decomposition processes. At the same time, unsaturation of oyster fatty acids decreased, suggesting a diet change, acclimatization to increasing temperature or, most likely, oxidative damage due to an enhanced production of reactive oxygen species, which are often associated with stressful situations. Wild-collected and hatchery-produced oysters, which exhibited different mortality patterns, showed persistent differences in fatty acid (20:5n-3 and 22:6n-3) content in their membrane, despite the fact that they were reared in the same environment. Mortality started when fatty acid 20:4n-6 content increased to $\sim 3 \%$ in the polar lipids, suggesting that this ratio could make a useful indicator of mortality risk. Finally, the 2008 mortality event coincided with a nationwide increase of $\sim 1.5^{\circ} \mathrm{C}$ in winter seawater temperature, which may impact the oyster and its pathogens.
\end{abstract}

KEY WORDS: Bivalves · Energetic reserve $\cdot$ Environment $\cdot$ Fatty acid $\cdot$ Summer mortality $\cdot$ Trophic signatures $\cdot$ Temperature

\section{INTRODUCTION}

Since the mid-1970s, large-scale episodic events such as disease epidemics, mass mortalities, harmful algal blooms and other population explosions have been occurring in marine environments at a historically unprecedented rate (Harvell et al. 1999, 2002, Hayes et al. 2001, Lafferty et al. 2004, Mydlarz et al.
2006). Ecologically and economically important invertebrates from most phyla, from sponges to echinoderms, have been affected by large-scale mass mortalities (Mydlarz et al. 2006). Although mass mortality phenomena are often related to infectious diseases, they can also reflect environmental changes that lead to an unfavourable energetic balance in these animals. To integrate these influencing factors and consider 
their relative importance, a model was recently proposed to explain the summer mortality of the Pacific oyster Crassostrea gigas in France, incorporating the animal, its pathogens and the environment (Samain \& McCombie 2008).

According to this model, mortalities occur when seawater temperature exceeds 19 to $20^{\circ} \mathrm{C}$ during the spring-summer period. Once temperatures exceed this threshold, oysters usually reach the pre-spawning stage characterized by a negative energy budget: energetic resources attain their lowest level whereas energy demand and reproductive effort are at their highest (Soletchnik et al. 1997, 2006, Berthelin et al. 2000, Delaporte et al. 2006, Samain \& McCombie 2008). Oyster haemocytes, circulating cells that play an important role in defence, also show their lowest performance at this time (Delaporte et al. 2006, Gagnaire et al. 2006, Li et al. 2009). Finally, although very little information is available on the effect of environmental temperature and pathogen virulence, 19 to $20^{\circ} \mathrm{C}$ probably represents a threshold above which metabolic activities of pathogens are high (Samain \& McCombie 2008). Therefore, pre-spawning oysters are characterized by energetic and immune weaknesses that render them more sensitive to pathogen infections. However, these physiological traits of oysters during reproduction occur every year and their pathogens have always been present. These factors alone are not enough to trigger mass mortality, as, according to this model, environmental stresses are also necessary.

Primary productivity in coastal areas increases with nutrients, which themselves vary as a function of natural conditions (rainfall and river discharge) and anthropogenic influences such as run-off from agricultural catchments. Excessive rainfall and nutrient inputs can sometimes lead to eutrophication, with increasing levels of primary productivity that cause degradation of benthic habitats by decreasing dissolved oxygen levels and redox conditions in sediments and bottom waters (e.g. Kemp et al. 2005). Eutrophication, therefore, has long been considered to be a triggering factor of summer mortality in oysters (Mori 1979) although it seems that extreme eutrophication is not necessary for a mortality episode to occur. Recent studies show that high phytoplankton concentration can favour summer mortality by enhancing the reproductive effort at the expense of the oyster defence system (Delaporte et al. 2006, Samain \& McCombie 2008). Therefore, environmental factors such as rainfall, freshwater run-off, primary productivity and hypoxia are all linked and can contribute to summer mortality in weakened prespawning oysters.

Mass mortalities of Crassostrea gigas have been reported in many areas of the world where this species is cultivated: in Japan (Mori 1979), the USA (Perdue et al.
1981, Cheney et al. 2000, Friedman et al. 2005), Mexico (Luna-González et al. 2009), and Western Europe (France: Soletchnik et al. 2007, Germany: Watermann et al. 2008 and Ireland: Malham et al. 2009). During spring-summer 2008, mass mortality of 1-yr-old C. gigas occurred simultaneously along all coasts of France. The 2008 mortality event represented the most serious ecological crisis in the French oyster production since the introduction of $C$. gigas in the 1970s. One-year-old oysters were decimated at 40 to $100 \%$, depending on locations and batches, whereas older animals were generally much less affected. In contrast to previous mortality events during past decades, oysters cultivated in Mediterranean lagoons were severely impacted in 2008, with only a few sites remaining free of mortality.

During spring-summer 2007, unusual mortality of 1 -yr-old oysters was reported by several growers in Mediterranean lagoons, whereas other cultivation areas in France remained free of any notable mortality (see www.ifremer.fr/lerlr/actualites/mortnaissain.htm; in French). This Mediterranean mortality event may not have followed the typical pattern shown by the interaction model of oyster summer mortality, in which reproductive effort is pivotal. Indeed, the 2007 mortality severely hit triploid oysters, which generally show a limited allocation to reproduction compared with diploids. This study was also motivated by our overall lack of information on the summer mortality phenomenon in Mediterranean lagoons where environmental conditions contrast those occurring along the English Channel and Atlantic coasts.

Our first objective was to examine environmental parameters in the Mediterranean Thau lagoon in relation to oyster mortality. Indeed, as mortality events result from a combination of factors, in a different manner from one ecosystem to another, there is a need for site-specific investigations of environmental parameters to provide a better understanding of the summer mortality phenomenon (Soletchnik et al. 2007). To this end, seawater temperature, salinity, rainfall, phytoplankton concentration and quality, and dissolved oxygen concentrations were analysed parallel to mortality monitoring. To further understand why 2008 was an exceptional year (as revealed by the results we recorded and by losses sustained in the oyster industry), these environmental parameters were compared with values recorded between 1997 and 2006-a period when no mortality was recorded. In our study, 5 batches of oysters were placed in the Mediterranean Thau lagoon from March to August 2008 for mortality assessment.

The second objective of our study was to quantify energetic reserves of oysters in relation to the timing of mortality. Here we hypothesized that mortality may 
have occurred when energetic reserves were exhausted, as previously observed by Soletchnik et al. (2006) in Marennes-Oléron Bay (France). Whole tissues of 1-yr-old oysters were therefore regularly analysed for organic matter, sugar, protein and lipids, in parallel with mortality and environmental parameters.

Finally, the third objective was to examine the fatty acid composition of reserve and membrane lipids. Indeed, fatty acids are incorporated largely unaltered into the reserve lipids of primary consumers like oysters, so they reflect the fatty acid profiles of food consumed and could therefore reveal useful information about trophic sources and interactions (Delaunay et al. 1993, Dalsgaard et al. 2003).

In contrast, the fatty acid composition of cell membranes is less sensitive to dietary changes. Membrane composition underlies inter-specific variation in metabolic rate and the degree of oxidative stress and damage at the cellular level (Hulbert \& Else 1999, Hulbert et al. 2007). Membrane composition also varies as a function of environmental temperature. Ectothermic animals compensate the effect of temperature on membrane fluidity by changing the fatty acids in their membranes, a process known as homeoviscous adaptation (Hazel 1995). Given that membrane adaptation is viewed as a central contributor to metabolic rate (Hulbert \& Else 1999), temperature adaptation and acclimatization in all organisms (Hochachka \& Somero 2002), this trait may be particularly useful for improving our understanding of the summer mortality phenomenon, which reflects a lack of adaptive capacity in Crassostrea gigas when animals are faced with temperatures exceeding $19^{\circ} \mathrm{C}$.

Twenty-carbon polyunsaturated fatty acids (PUFA) represent precursors of eicosanoids, a group of highly biologically active hormones that includes prostaglandins, leukotrienes and hydroxyeicosatetraenoic acids (Smith \& Murphy 2003). Eicosanoid production is associated with stressful or energetically expensive situations such as gametogenesis and spawning in bivalves or stimulation of immune function in other invertebrates (Osada \& Nomura 1989, Stanley \& Howard 1998). In bivalves, membrane lipids of hemocytes are characterized by elevated amounts of arachidonic acid (20:4n-6), presumably to regulate immune responses (Delaporte et al. 2003). Fatty acid composition was therefore recorded, particularly 20:4n-6 as this is an indicator of health and stress in bivalves, because this information may prove useful for understanding the summer mortality phenomenon from a biochemical perspective.

The novelty of our study is that it was performed in a Mediterranean lagoon where summer mortality of young oysters $(<1$ yr old) is a new phenomenon and environmental conditions contrast with those occur- ring along the English Channel and Atlantic coasts where the problem has occurred in the past and where previous studies on oyster mortality have been conducted. Furthermore, this study is the first to provide a comprehensive view of fatty acid dynamics, whose characteristics are linked to food quality, metabolism, thermal adaptation and stress of Pacific oysters, in relation to a mass mortality event.

\section{MATERIALS AND METHODS}

Study area. The Mediterranean Thau lagoon is an oyster farming area that accounts for about $10 \%$ of French Pacific oyster production. Growth rates are among the highest in France for this species (Soletchnik et al. 1997). The Thau lagoon is $19 \mathrm{~km}$ long, $4.5 \mathrm{~km}$ wide and $5 \mathrm{~m}$ deep on average (Fig. 1). Shellfish are cultured in 3 areas of the lagoon, covering about $20 \%$ of the total surface. The lagoon is connected with the Mediterranean Sea through the narrow Sète channel, other connections being negligible in terms of water exchange.

Environment. Monthly mean water temperature $\left({ }^{\circ} \mathrm{C}\right)$, salinity, chlorophyll a $(\mathrm{chl} \mathrm{a})\left(\mu \mathrm{g}^{-1}\right)$ and phytoplankton concentration (cell $\mathrm{l}^{-1}$ ) were measured by Ifremer's REPHY network (Phytoplankton and Phycotoxin Monitoring Network, see Gailhard et al. 2002, Guarini et al. 2004 for further information). REPHY sampling in the Thau lagoon has been conducted every $14 \mathrm{~d}$ since 1984 in the 'Bouzigues' area situated in the north-eastern part of the lagoon (Fig. 1). Temperature and salinity were measured in situ using a WTW ProfiLab LF597-5 salinometer (Sigma-Aldrich, Lyon, France) and water samples taken between 0.5 and $1.0 \mathrm{~m}$ deep with a 21 standard water sampler (Hydro-Bios, Kiel, Germany). Each water sample was divided between 2 bottles: one for chl a determination, the other for phytoplankton identification. Samples for chl a determination were filtrated using Whatman $\mathrm{GF} / \mathrm{F}$ filters and stored at $-20^{\circ} \mathrm{C}$ until analysis, conducted by standard spectrophotometry (Aminot \& Kérouel 2004). Samples for phytoplankton identification were preserved with Lugol's solution $\left(1 \mathrm{ml} \mathrm{l}^{-1}\right)$. Ten $\mathrm{ml}$ were placed in a phytoplankton chamber for sedimentation for at least $6 \mathrm{~h}$. The sample in the chamber was identified and counted using an inverted microscope (Olympus IMT 2, Olympus, Japan), at 40x. Most species were aggregated at their genus level. Daily rainfall, measured at the weather office in Sète, was obtained from the Météo France database. Monthly means of each environmental parameter measured between September 2007 and August 2008 were compared with minima, maxima and means of data recorded during the 1997-2006 period. 


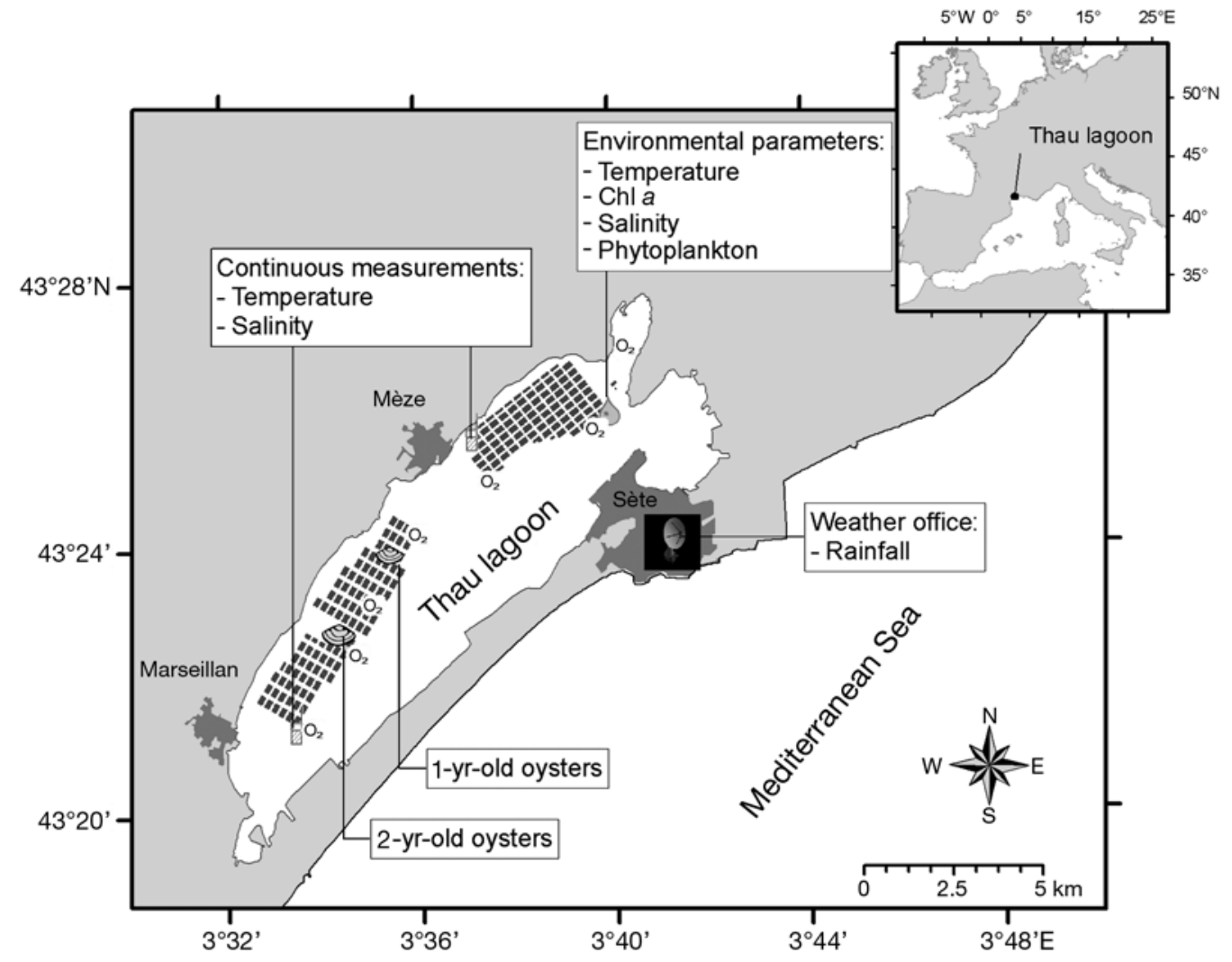

Fig. 1. Thau lagoon sampling sites. $\mathrm{O}_{2}$ indicates the locations where dissolved oxygen measurements were taken. Checked area: oyster banks

Temperature and salinity were also recorded every 10 min by means of 2 autonomous CTD multiparameter recorders (NKE instrumentation, Hennebont, France) deployed at 2 locations within the oyster farming area of the lagoon: in the south-western area, at the 2-yr-old oysters deployment and experiment site (see below), and in the Bouzigues area, halfway between the 1-yr-old oysters experiment site and the REPHY sampling site (Fig. 1).

Dissolved oxygen (DO) levels were measured every week from 16 June using a WTW ProfiLab 197s oximeter (Sigma-Aldrich, Lyon, France). Oxygen measurements were taken at 3 depths (surface: $0.5 \mathrm{~m}$, middle: $2.6 \mathrm{~m}$, and bottom: $5.6 \mathrm{~m}$ ) at 7 locations (Fig. 1). Oxygen is a critical environmental parameter in the Thau lagoon, as dystrophic crises known as 'malaigue' occur sporadically causing another kind of mass mortality phenomenon (Chapelle et al. 2001).

Experimental design and biometry. One-year-old oysters: For this experiment, 1-yr-old Pacific oysters Crassostrea gigas (Thunberg 1793) were collected in the field (i.e. wild seed) or produced in hatcheries. Wild oysters were initially collected in August 2007 in plastic tubes (collectors) suspended in the water column in a farming site located in Marennes-Oléron Bay, France $\left(45^{\circ} 58^{\prime} \mathrm{N}, 1^{\circ} 07^{\prime} \mathrm{W}\right.$; Site La Mouclière). These oysters were cultured in the same growing area following usual local practices: they were separated from their collectors during the winter and placed in mesh bags, which were then attached to iron racks to raise them slightly off the bottom. Hatchery oysters were obtained from 3 French commercial hatcheries (A, B and C). Hatcheries A and B provided triploid animal (C 3n and B 3n, where n refers to ploidy level), whereas hatchery C supplied both diploid and triploid oysters (C 2n, C 3n). The triploid oysters had been produced by diploid $\times$ tetraploid crosses during spring 2007. Both wildcollected and hatchery-bred oysters were transferred to the Ifremer Laboratoire Environnement Ressources en Languedoc-Roussillon, Sète, France $\left(43^{\circ} 23^{\prime} \mathrm{N}, 3^{\circ} 4^{\prime} \mathrm{E}\right.$; Fig. 1) in early March 2008. Oysters from hatchery A arrived 1 month later (3 April).

Upon arrival at Ifremer Sète, 100 individuals from each group were measured and weighed for initial characterization. The 5 groups of oysters presented small but significant differences in shell length and total body mass. Mean shell length and total body mass among groups were $11.4 \pm 1.8 \mathrm{~mm}$ and $0.205 \pm$ $0.034 \mathrm{mg}$ respectively. Tukey multiple comparison tests showed that initial shell length of $\mathrm{A} 3 \mathrm{n}>\mathrm{B} 3 \mathrm{n}=$ wild $>C 2 n>C 3 n$, whereas total body mass of B3n = $\mathrm{A} 3 \mathrm{n}=\mathrm{C} 2 \mathrm{n}>$ wild-collected $>\mathrm{C} 3 \mathrm{n}$. Oysters were 8 mo 
(wild) or 11 mo old (hatchery) since settlement at the beginning of our study. In the Thau lagoon, oysters are cultivated in pearl nets fixed on ropes, which are suspended in the water column from culture tables. In our experiment, 4000 oysters per group were equally distributed between 16 pearl nets (initial density $=250$ individuals per pearl net). Groups of 4 pearl nets were attached together on a single 'rope', so that there were 4 ropes used for each group. Rope length was $6 \mathrm{~m}$ and pearl nets were deployed at $0.5,1.5,2.5$ and $3.5 \mathrm{~m}$ depth. The ropes were hung from the culture table of a grower located in the central part of the lagoon on 18 March (Fig. 1). In total, we followed 80 pearl nets of oysters: 5 origins $\times 4$ ropes $\times 4$ depths (pearl net).

One-yr-old oysters were scored for mortality and samples measured for shell length, total wet mass, and biochemical parameters on 7 dates, in 2008: 16 April, 13 May, 27 May, 10 June, 24 June, 9 July and 22 July. Oysters were also sampled twice to determine their reproductive stages: 27 May and 9 July. Mortality was evaluated in each pearl net and calculated as dead/ initial number $\times 100$. Shell length and total wet mass were measured individually on a sub-sample of 25 oysters from each pearl net. Shell length, defined as the greatest anteroposterior dimension, was measured with a digital calliper (Mitutoyo, Paris, France) and total wet mass was recorded with a Mettler precision balance (Mettler-Toledo, Viroflay, France). Reproductive stage was determined following a qualitative classification (5 stages: 0 to 4 ) based on visual evaluation of the relative size, shape and colour of the gonads. Briefly, Stage 0 corresponds to an empty gonad and thus sexual repose or the end of the gamete release period; Stage 1 corresponds to early gametogenesis activity where sex can be determined; Stage 2 corresponds to a well developed gonad beginning to fill; Stage 3 refers to a complete, full gonad covering the visceral tissue and containing abundant gametes; and Stage 4 corresponds to the release of gametes, with a gonad that has become colourless and watery in appearance.

Two-year-old oysters: Animals were initially collected in the field at Arcachon and grown in a farming site in northern Brittany for 2 yr. These oysters were transferred to the Ifremer marine station at Sète on 5 March 2008. Upon arrival at the marine station, 70 individuals were measured and weighed for initial characterization. In Thau lagoon oyster culture, oysters that are large enough (i.e. shell length $>3$ to $4 \mathrm{~cm}$ ) are cemented on ropes, which are then suspended in the water column from culture tables (see Gangnery et al. 2003 for a description of culture tables). In our experiment, an initial number of 1260 oysters were cemented onto 21 ropes (60 oysters per rope). The ropes were deployed on the Ifremer culture table, located in the south-western part of the lagoon on 12 March (Fig. 1). The objective of this transplantation was to provide baseline data on mortality of 2-yr-old oysters for comparison with that of 1-yr-olds. Previous observations suggest that 1-yr-old animals were less resistant to the mortality in 2007 than 2-yr-old oysters. Oysters were scored for mortality and sampled for flesh dry mass measurements at least once a month. Four ropes were dedicated to mortality assessment, and oysters cemented on the other 17 ropes were randomly sampled for flesh dry mass measurements.

Biochemical analyses on 1-yr-old oysters. From each rope, four 1-yr-old oysters (1 oyster per pearl net) were collected, pooled together and stored at $-80^{\circ} \mathrm{C}$ for biochemical analyses. When the oysters were too small to allow proper biochemical analyses with only 4, 8 were collected per rope. Biochemical analyses were performed on wild-collected oysters and the triploid animals from hatchery $B$. These 2 groups represent the usual type of seed currently cultivated by oyster farmers in France.

Each pool of 4 or 8 oysters was ground with a Dangoumeau homogeniser at $-180^{\circ} \mathrm{C}$ and sub-sampled for ash-free dry wt (organic matter), sugar, protein and lipid analysis. Samples for organic matter (1 g) were placed in pre-weighed aluminium cups, dried for $72 \mathrm{~h}$ at $60^{\circ} \mathrm{C}$ and weighed. The samples were then burnt at $500^{\circ} \mathrm{C}$ for $24 \mathrm{~h}$ and the remaining ashes weighed on a Mettler microbalance. Samples for sugar and protein measurements $(750 \mathrm{mg}$ ) were placed in Eppendorf tubes containing $3 \mathrm{ml}$ of nanopure water and stored at $-80^{\circ} \mathrm{C}$ until analyses. Sugar and protein contents were measured colorimetrically as described by DuBois et al. (1956) and Lowry et al. (1951), respectively. Finally, further aliquots (300 mg) were placed in amber glass vials filled with $3 \mathrm{ml}$ of chloroform-methanol $(2: 1 \mathrm{v} / \mathrm{v})$ for further lipid analysis. An aliquot of the sample $\left(\mathrm{CHCl}_{3}-\mathrm{MeOH}\right.$ mixture) was evaporated to dryness and lipids recovered with three $500 \mathrm{ml}$ washings of $\mathrm{CHCl}_{3}-\mathrm{MeOH}(98: 2 \mathrm{v} / \mathrm{v})$. The lipids were placed at the top of a silica gel microcolumn $(30 \times 5 \mathrm{~mm}$ internal diamater; Kieselgel; 70-230 mesh [Merck, Lyon, France]; previously heated to $450^{\circ} \mathrm{C}$ and deactivated with $5 \%$ water). The neutral lipids were eluted with $10 \mathrm{ml}$ $\mathrm{CHCl}_{3}-\mathrm{MeOH}$ mixture (98:2 v/v). The polar lipids were recovered with $15 \mathrm{ml}$ of methanol. A known amount of 23:0 fatty acid was added to both neutral and polar fractions as an internal standard. Lipids were transesterified with $10 \mathrm{wt} \%$ boron trifluoride-methanol (Metcalfe \& Schmitz 1961) and analysed according to the method described by Marty et al. (1992). The fatty acid methyl esters (FAME) were analysed in a gas chromatograph with an on-column injector, a DB-Wax (30 m $\times 0.25 \mathrm{~mm} ; 0.25 \mu \mathrm{m}$ film thickness) capillary column and a flame ionization detector. Hydrogen was 
used as the carrier gas. The fatty acids were identified by comparing their retention times with those of standards. Masses of neutral and polar lipids were assessed by summation of fatty acids.

Statistical analyses. Three-way analyses of variance (ANOVA) with repeated measurements were conducted to determine differences in mortality, shell length and total wet mass of 1-yr-old oysters according to their origin (fixed between-subjects factor with 5 levels [wild-collected, A 3n, B 3n, C 3n, C 2n]), depth (fixed between-subjects factor with 4 levels $[0.5,1.5$, 2.5 and $3.5 \mathrm{~m}]$ ), sampling time (random factor with 7 levels of repeated measurements) and all their mutual interactions (Table 1). Differences in organic matter (\% of total body mass), proximal composition (sugar, protein and total fatty acids), and fatty acid composition of neutral and polar lipids were analysed by means of

Table 1. Crassostrea gigas. 1-yr-old oysters. Factorial 3-way repeated measure ANOVA on the effect of oyster origin (field collection, hatchery A triploid, B triploid, C triploid and C diploid), depth $(0.5,1.5,2.5$ and $3.5 \mathrm{~m})$ and sampling time $(7$ dates between 18 March and 22 July 2008) on biometrical parameters of Pacific oysters. Biochemical analyses performed on oysters from the wild (natural settlement) and hatchery B triploid batch only. As 1 or 2 oysters per pearl net (depth) were pooled together after sampling, depth effect was not assessed. Biometrical variables include: cumulative mortality $(\%)$, shell length $(\mathrm{mm})$ and mass of oysters $(\mathrm{g})$; Biochemical variables include: organic matter (\%), proximal composition (sugar, protein and total fatty acids as expressed as mass $\%$ of organic matter), fatty acid composition of neutral and polar lipids $(\mathrm{mol} \%)$

\begin{tabular}{|c|c|c|}
\hline Source of variation & $\begin{array}{c}\text { Biometrical } \\
\text { df }\end{array}$ & $\begin{array}{c}\text { Biochemical } \\
\text { df }\end{array}$ \\
\hline \multicolumn{3}{|l|}{ Between subject analysis } \\
\hline Origin & 4 & 1 \\
\hline Depth & 3 & \\
\hline Origin $\times$ Depth & 12 & \\
\hline Error A & 60 & 5 \\
\hline \multicolumn{3}{|l|}{ Within subject analysis } \\
\hline Time & 6 & 5 \\
\hline Time $\times$ Origin & 24 & 5 \\
\hline Time $\times$ Depth & 18 & \\
\hline Time $\times$ Origin $\times$ Depth & 72 & \\
\hline Error B & 360 & 30 \\
\hline
\end{tabular}

2-way ANOVA with repeated measurements according to oyster origin (fixed between-subjects factor with 2 levels [wild-collected and B3n]) and sampling time (random factor with 7 levels of repeated measurements) and their interactions (Table 2). Mauchly's test $(\alpha=0.05)$ was used to assess whether datasets conformed to the sphericity assumption required for a repeated measure analysis. When the sphericity assumption was not met, the df were adjusted accordingly using the Greenhouse-Geisser or Huynh-Feldt correction. Significant differences between all possible combinations of sample means were also assessed using Tukey's Honestly Significant Difference (HSD) test $(\alpha=0.05)$. Residuals were tested for normality using the Kolmogorv-Smirnov test. Variance homogeneity was determined with Levene's test. All statistical analyses were performed with SPSS 13.0 (SPSS Inc., Chicago, IL, USA).

\section{RESULTS}

\section{Environment}

Monthly mean seawater temperatures recorded between 1997 and 2006 varied from $7.0^{\circ} \mathrm{C}$ in January to $24.5^{\circ} \mathrm{C}$ in July (Fig. 2A). Those recorded in 2008 were similar to those recorded during the 1997-2006 period except during the winter. Indeed, in January and February 2008, mean temperatures were $8.5^{\circ} \mathrm{C}$ and $8.8^{\circ} \mathrm{C}$, respectively, in contrast to $7.0^{\circ} \mathrm{C}$ and $7.6^{\circ} \mathrm{C}$ during the 1997-2006 period. This pattern was also reflected in oyster-growing areas elsewhere in France (Anonymous 2008). Continuous seawater temperature profiles showed a marked increase between 20 April and 8 May (increase from $13.5^{\circ} \mathrm{C}$ to $19.8^{\circ} \mathrm{C},+6.2^{\circ} \mathrm{C}$ in $18 \mathrm{~d}$ ) and between 17 June and 2 July, during which temperature increased from $21^{\circ} \mathrm{C}$ to the highest value recorded in $2008\left(27.2^{\circ} \mathrm{C},+6.3^{\circ} \mathrm{C}\right.$ in $\left.15 \mathrm{~d}\right)$.

Monthly salinity means recorded in 2008 ranged from 37.1 to 39.1. These values are well above those recorded during the 1997-2006 period, which varied seasonally from 33.8 in February and March to 38.1 in August and September (Fig. 2B). These exceptionally high salinities reflected a strong deficit in precipitation

Table 2. Dissolved oxygen concentrations $\left(\mathrm{mg} \mathrm{l}^{-1}\right)$ in the Mediterranean Thau lagoon during summer 2008 as a function of depth (bottom, mid, surface) and time (depth $\times$ time effect, $\left.F_{9.7,53.5}=3.0, \mathrm{p}=0.005\right)$. Data: means $\pm \mathrm{SD}(\mathrm{n}=7$ locations $)$

\begin{tabular}{|c|c|c|c|c|c|c|c|}
\hline Depth (m) & 16 Jun & 23 Jun & 30 Jun & $07 \mathrm{Jul}$ & $15 \mathrm{Jul}$ & $21 \mathrm{Jul}$ & $28 \mathrm{Jul}$ \\
\hline 5.6 (bottom) & $7.5 \pm 0.5^{\mathrm{ad}}$ & $7.5 \pm 1.2^{\mathrm{ad}}$ & $5.9 \pm 0.7^{\mathrm{eg}}$ & $5.2 \pm 0.7^{g}$ & $5.8 \pm 0.2^{\mathrm{fg}}$ & $3.4 \pm 1.0^{\mathrm{h}}$ & $5.2 \pm 1.5^{\mathrm{g}}$ \\
\hline 2.6 (mid) & $7.6 \pm 0.5^{\mathrm{ac}}$ & $7.7 \pm 0.8^{\mathrm{ab}}$ & $6.8 \pm 1.0^{\mathrm{af}}$ & $5.2 \pm 0.7^{9}$ & $5.9 \pm 0.3^{\mathrm{eg}}$ & $3.3 \pm 0.8^{\mathrm{h}}$ & $6.1 \pm 0.5^{\mathrm{bg}}$ \\
\hline 0.5 (surface) & $7.2 \pm 0.4^{\text {af }}$ & $7.8 \pm 0.3^{\mathrm{a}}$ & $7.3 \pm 0.7^{\mathrm{ae}}$ & $5.3 \pm 0.6^{g}$ & $6.0 \pm 0.2^{\mathrm{dg}}$ & $3.4 \pm 0.9^{\mathrm{h}}$ & $6.1 \pm 0.5^{\mathrm{cg}}$ \\
\hline
\end{tabular}


in 2008 (Fig. 2C). Indeed, winter 2007-2008 was the driest of the last $10 \mathrm{yr}$ : cumulated rainfall from September 2007 to February 2008 was only 164 mm compared with average value of $388 \pm 143 \mathrm{~mm}$ in 1997 to 2006 at
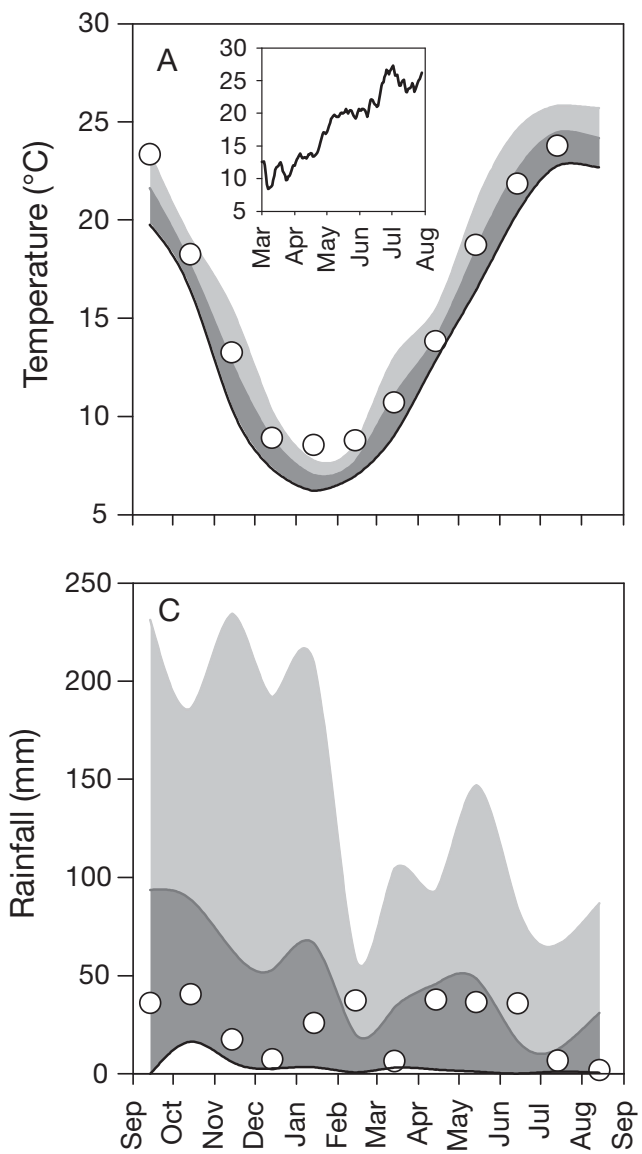

the same period of the year. In addition, cumulated rainfall from March to July 2008 was slightly below the average value recorded for 1997 to 2006 at the same time of year (123 mm vs. $165 \pm 88 \mathrm{~mm}$ respectively).
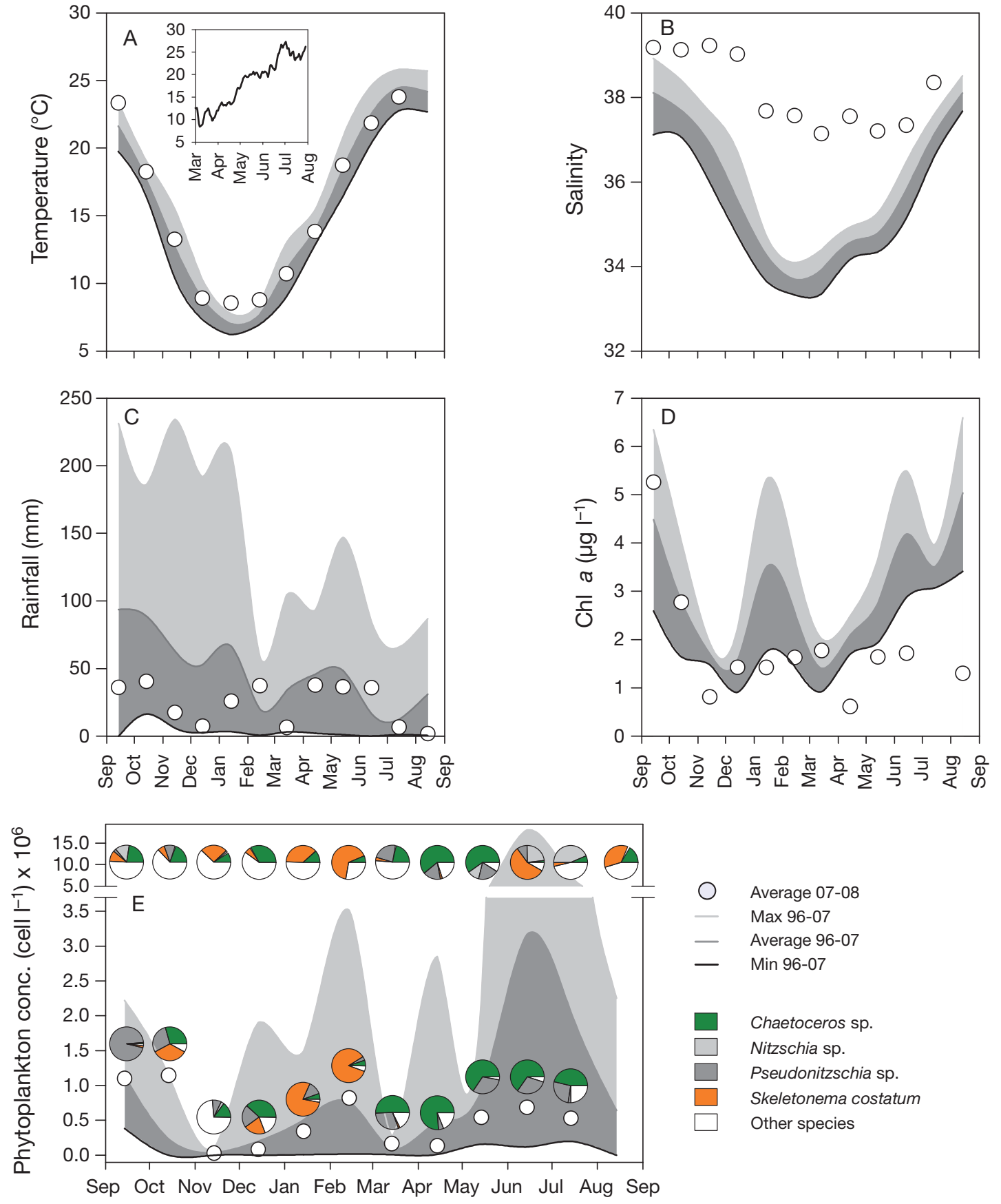

Fig. 2. Environmental parameters in the Thau lagoon over 1 yr: (A) seawater temperature, (B) salinity, (C) rainfall, (D) concentration of chl $a$ and (E) concentration of phytoplankton. Circles $=2007-08$ monthly means; Area plots = monthly minima, maxima and means calculated from 1996 and 2007 measurements. (A) Inset = continuously recorded seawater temperature. (E) Pie charts = relative abundance of each taxonomic group or species of phytoplankton based on 2007-08 monthly means (bottom), and average values measured between 1996-2007 (top) 
Monthly mean chl a concentration in 1997 to 2006 showed strong seasonal variations: peaks were observed during the winter in February, during the spring in June and more importantly in late summer to early fall (August and September, Fig. 2D). These seasonal variations in chl $a$ are a good reflection of those observed in phytoplankton concentrations (Fig. 2E). From April to August 2008, both chl $a$ and phytoplankton concentrations were lower than average values recorded over the previous $10 \mathrm{yr}$ at the same period. During the 1997-2006 period, phytoplankton communities were dominated by the diatoms Skeletonema costatum during the winter bloom in February, Chaetoceros sp. during the spring bloom, and S. costa- tum and Nitzschia sp. during the summer (Fig. 2E). Phytoplankton communities in 2008 were similar to those observed during the 1997-2006 period until the summer, when they remained dominated by Chaetoceros sp.: there was no transition toward the previously observed mixed community of $S$. costatum and Nitzschia sp.

Dissolved oxygen concentrations remained constant at $\sim 7.5 \mathrm{mg} \mathrm{l}^{-1}$ until 23 June. On 30 June, a slight decrease in DO started at the bottom of the lagoon and attained $5.2 \mathrm{mg} \mathrm{l}^{-1}$ in the entire water column on 7 July. On 21 July, DO reached its lowest level $\left(3.3 \mathrm{mg} \mathrm{l}^{-1}\right)$ but increased thereafter, attaining saturation at the sea surface.
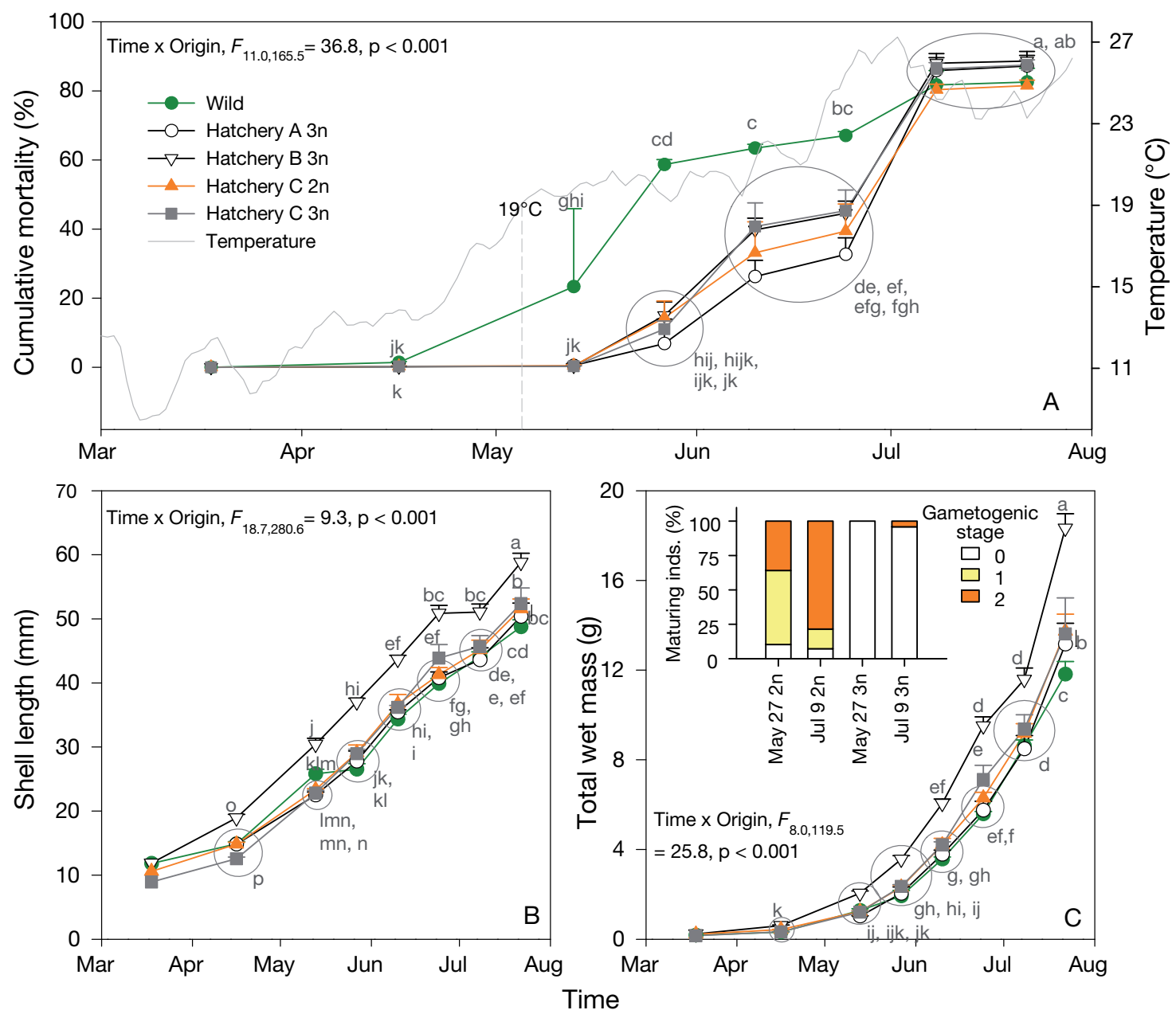

Fig. 3. Crassostrea gigas. 1-yr-old oysters. (A) Cumulative mortality (left axis) and seawater temperature (right axis), (B) shell length and $(\mathrm{C})$ total wet mass of oysters as a function of time $\times$ origin. $(\mathrm{C})$ Inset $=$ reproductive stage as a function of time and ploidy (2n: diploid, 3n: triploid) (see 'Materials and methods' for description of gametogenic stages, $\mathrm{n}=14-81$ individuals, oysters from different origins were pooled together as a function of their ploidy level). Oysters were collected in the field or produced in commercial hatcheries. Letters indicate significant differences. Repeated measures ANOVA with Greenhouse-Geisser (A,C) or Huynh-Feldt (B) corrections to assess whether there were differences among combinations of time and origin. Circled areas represent homogeneous subgroups when there was no significant difference. Data: mean \pm SD between ropes $(n=4)$. Each rope included 4 pearl nets where 250 individuals were initially deployed 


\section{Mortality, growth and gametogenesis}

Time and oyster origin affected mortality of 1-yr-old oysters through their interaction (Fig. 3A). Mortality in young oysters occurred in 2 phases: between 13 May and 10 June and between 24 June and 9 July (Fig. 3A). These mortality events followed marked increases in seawater temperature. The first occurred after temperature had been at $19^{\circ} \mathrm{C}$ for a few days and affected 26 to $40 \%$ of hatchery-bred oysters and $63 \%$ of wildcollected oysters. The second mortality event was stronger than the first and 41 to $53 \%$ of oysters died (but only $15 \%$ of those originating from the wild). Wild-collected oysters therefore showed mortality earlier than those bred in hatcheries. However, at the end of the study period, all groups of oysters showed $85.5 \pm$ $3.2 \%$ mortality, irrespective of their origin and ploidy (Fig. 3A).

Time and origin of oysters showed a significant interaction effect on shell length and total wet mass (Fig. 3B,C). Shell length of oysters increased from 11.4 to $52.2 \mathrm{~mm}$ during the study period, corresponding to an average growth rate of $318 \mu \mathrm{m} \mathrm{d}^{-1}$ (Fig. 3B). Nevertheless, shell length of oysters remained constant when mortality occurred between 13 May and 27 May for wild-collected animals and between 24 June and 9 July in hatchery-bred oysters. Total wet mass of oysters increased exponentially with time, ranging from 0.2 to an average of $14.1 \mathrm{~g}$ at the end of the study (Fig. 3C). B 3n oysters showed a higher growth rate than oysters of other groups, both in terms of shell length and total wet mass (Fig. 3B,C). It is noteworthy that mortality and growth were not affected by depth or its interactions with other factors. Visual examination of visceral tissues of the 1-yr-old oysters on 2 occasions during the study period showed that diploid oysters underwent partial gametogenesis and reached Stage 2 (78\% on 9 July) whereas triploid animals remained at Stage 0 (Fig. 3C, inset). There was no evidence of spawning in any of these oysters.

Cumulative mortality of the 2-yr-old oysters was only $14 \%$ on 12 August, but increased slightly during the fall, reaching $29 \%$ on 9 October (Fig. 4). Dry flesh mass increased with time until 9 June. On 24 June, the dry mass of flesh had diminished by $1.5 \times$, indicating that spawning had occurred.

\section{Biochemical analyses of 1-yr-old oysters}

\section{Proximate}

The interaction between time and oyster origin affected changes in organic matter, expressed as \% of total dry body mass (including shell, Fig. 5A). During the first mortality event (13 May to 10 June), organic matter increased by $1.5 \times$ in wild-collected oysters, attaining a maximum of $5.1 \%$, whereas B 3n oysters showed constant levels of organic matter around 3.5\%. Between 10 June and 24 June, organic matter decreased by $0.8 \%$ in these 2 types of oyster. Although not statistically significant, this decrease represented a loss of $20 \%$ in organic matter. During the second mortality event (24 June to 9 July), organic matter increased by $1.5 \times$, attaining 6.1 and $4.2 \%$ in wildcollected and hatchery oysters, respectively.

Sugar levels (expressed as \% of organic matter) varied as a function of time $\times$ oyster origin (Fig. 5B). The initial level of sugar was $11.8 \%$ of the organic matter in wild-collected and hatchery (B 3n) oysters. It remained constant at a mean of $10.9 \%$ until 10 June for wild-collected oysters whereas hatcherybred animals showed significant variations during this time period. Between 10 June and 24 June, sugar level decreased by $60 \%$ to reach 4.6 and $5.1 \%$ in wild-collected and hatchery oysters, respectively. During the second mortality event, sugar levels increased markedly, attaining 10.9 and $15.1 \%$ in wildcollected and hatchery oysters, respectively.

Protein level varied as a function of time from 53.3 to $80.6 \%$ of organic matter, following an inverse pattern to that of sugar (Fig. 5C). Fatty acids in the neutral lipids (reserves) were low (0.6 to $1.9 \%$ ) and increased as a function of time, whereas fatty acids in the polar lipids (membranes) remained constant at $26.9 \%$ for wild-collected and hatchery oysters (Fig. 5D).

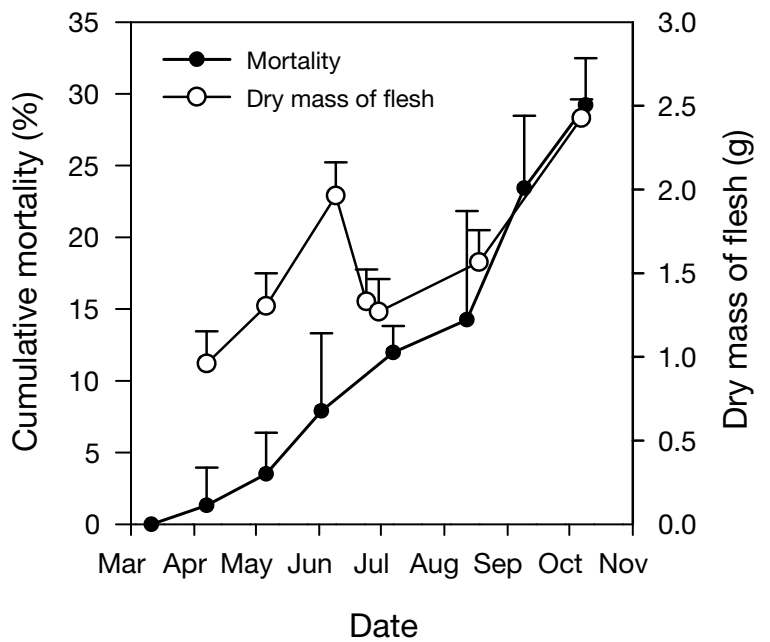

Fig. 4. Crassostrea gigas. 2-yr-old oysters. Cumulative mortality and dry flesh mass of 2-yr-old oysters as a function of time. Mortality data: means \pm SD between ropes $(n=4)$; dry flesh mass was measured from 30 oysters randomly selected among 17 ropes. Each rope initially bore 60 individuals 

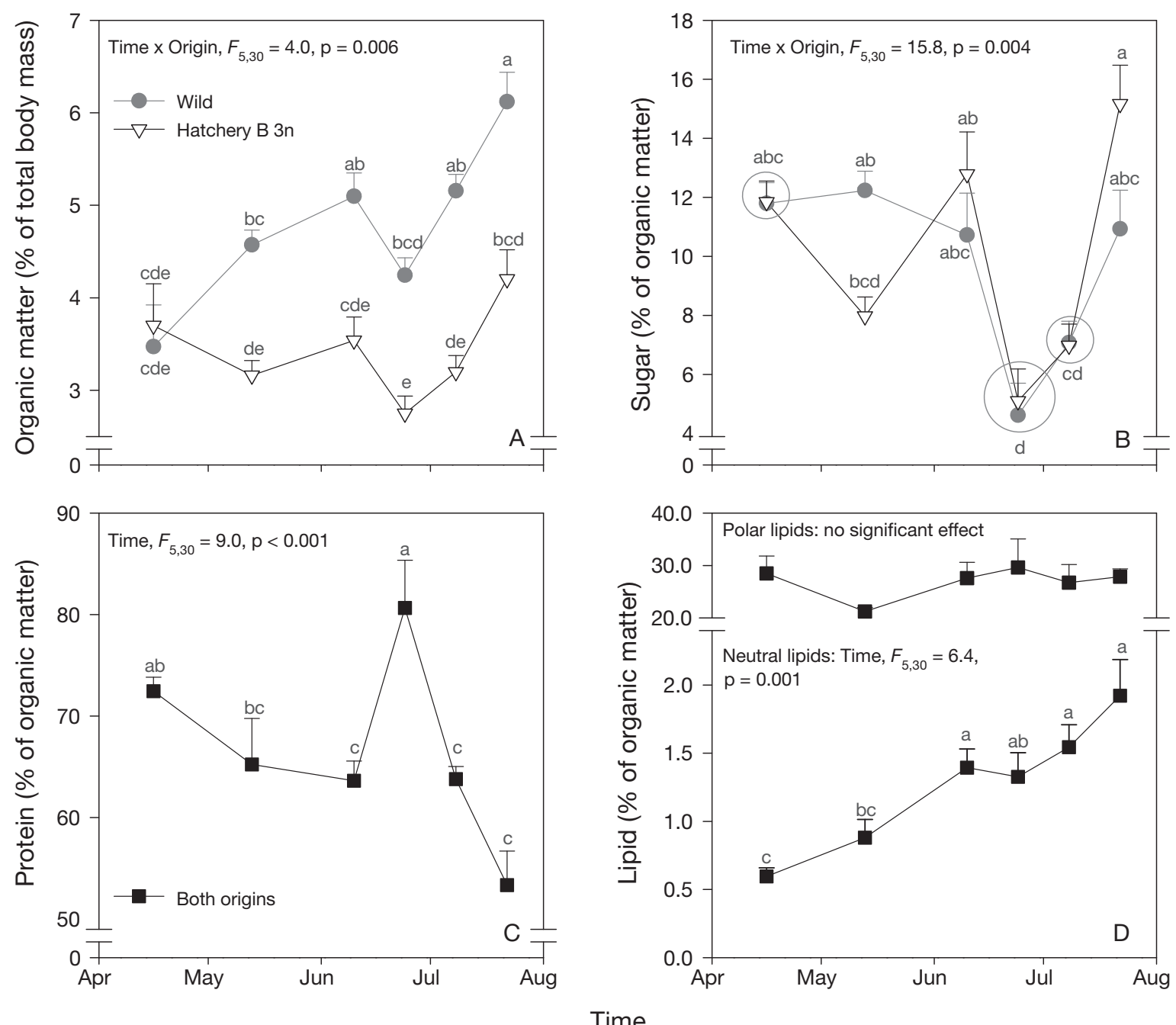

Fig. 5. Crassostrea gigas. 1-yr-old oysters. Relative concentrations of (A) organic matter, (B) sugars, (C) protein and (D) total fatty acids in neutral and polar fractions of oysters as a function of time $\times$ origin (when significant). Oysters were either wild-collected in the field, or commercial produced triploids in a hatchery. Letters indicate significant differences. Repeated measures ANOVA conducted to assess whether there were differences among combinations of time and origin. Data: mean \pm SE between ropes $(\mathrm{n}=4)$. Each rope included 4 pearl nets in which 1 or 2 oysters were sampled and pooled together

\section{Fatty acids}

The sum of iso- and anteiso-branched chain fatty acids and unbranched 15:0 and 17:0 in neutral lipids of oysters was used to evaluate the contribution of bacteria to the diet of the oysters (Budge \& Parrish 1998, Dalsgaard et al. 2003). Bacterial fatty acids remained at $\sim 2.9 \%$ of total fatty acids until 10 June, then increased $1.4 \times$ by 24 June before the second mortality event, and decreased thereafter (Fig. 6). It is also noteworthy that in the polar lipids of oysters, bacterial fatty acids remained constant at $2.6 \%$ irrespective of origin or time (data not shown).

Unsaturation index, which is the number of double bonds per 100 molecules of fatty acids, varied as a function of time in both neutral and polar lipids (Fig. 7A,B). In neutral lipids, this index remained constant at 212 until 10 June; it then decreased markedly, attaining a minimum of 184 on 9 July. In the polar lipids, unsaturation index remained constant at 290 until 10 June and then decreased by $10 \%$ attaining 261 on 24 June, just before the second mortality event.

The level of 22:6n-3 in the neutral lipids varied between 5.7 and $8.9 \%$ as a function of time $\times$ oyster origin, but followed no consistent pattern (Fig. 7C). In the polar lipids, this long-chain PUFA varied as a function of time and origin of oysters (main effects only, Fig. 7D). Indeed, 22:6n-3 showed 2 periods of marked decrease in both wild-collected and hatchery oysters. The first was from 16 April to 13 May, during which 


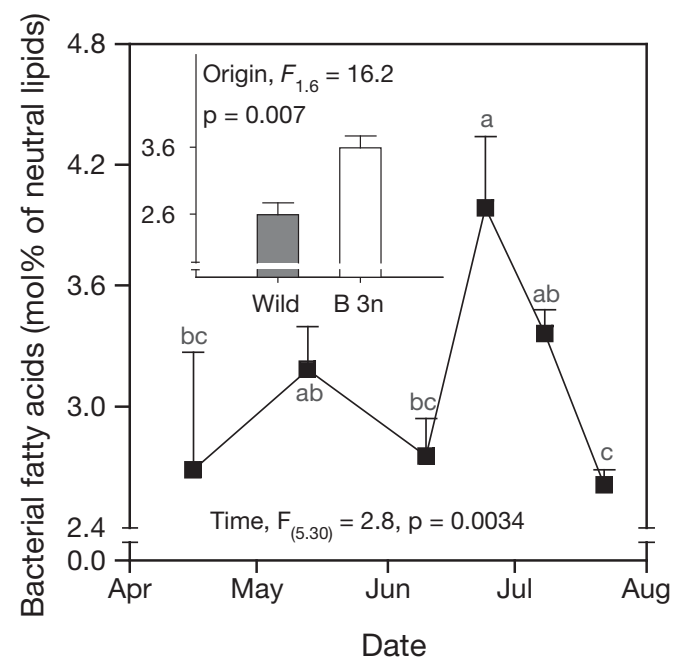

Fig. 6. Crassostrea gigas. 1-yr-old oysters. Bacterial fatty acids expressed as mol\% of total fatty acids in neutral lipids of oysters as a function of time and origin (inset). Bacterial fatty acids include iso- and anteiso-branched chain fatty acids and unbranched 15:0 and 17:0. Oysters were wild-collected in the field or were triploids produced in a commercial hatchery. Letters indicate significant differences. Repeated measures ANOVA were conducted to assess whether there were differences among combinations of time and origin. Data are mean \pm SE between ropes $(n=4)$. Each rope included 4 pearl nets from which 1 or 2 oysters were sampled and pooled together

22:6n-3 decreased from 20.9 to $16.9 \%$. The second was from 27 May to 9 July, during which 22:6n-3 decreased from 18.7 to $15.8 \%$. The level of $22: 6 n-3$ in the polar lipids was noticeably higher in B $3 n$ compared with wild-collected oysters (Fig. 7D, inset).

The level of 20:5n-3 varied as a function of time for neutral and polar lipids (Fig. 7E \& 5F). In the neutral lipids, $20: 5 n-3$ increased from 16.7 to $21.5 \%$ on 10 June and decreased suddenly thereafter to return to initial values just before the second mortality event that started on 24 June. In the polar lipids, 20:5n-3 had increased from 19.0 to $21.3 \%$ by 13 May and then remained constant until 10 June. On 24 June, 20:5n-3 decreased markedly (16.6\%), as observed in the neutral lipids. The level of 20:5n-3 in polar lipids was slightly higher in wild-collected oysters compared with B 3n oysters (Fig. 7F, inset).

Time and origin of oysters interacted in their effect on 20:4n-6 in both neutral and polar lipids (Fig. 7G,H). In the neutral lipids, 20:4n-6 remained constant until 9 July and increased slightly by 24 July in both wildcollected and B 3n oysters. From 24 June onwards, B 3n oysters showed higher levels of 20:4n-6 than wildcollected oysters. The level of $20: 4 n-6$ in the polar lipids of wild-collected oysters was initially $3.0 \%$, which is $1.4 \times$ higher than that of B $3 \mathrm{n}$ oysters $(2.1 \%$, Fig. $7 \mathrm{H}$ ). On 13 May, 20:4n-6 had increased to $3.2 \%$ in the polar lipids of B 3 n oysters, a level similar to that observed in wild-collected oysters. The level of 20:4n6 then increased further, to attain 4.4 and $5.3 \%$ on 9 July in wild-collected and B 3n oysters, respectively.

Overall, unsaturation index of the polar lipids was $1.4 \times$ higher compared to that of the neutral lipids of oysters, reflecting enrichment in 22:6n-3 and 20:4n-6 of the polar lipids. In contrast, 20:5n-3 is the only longchain PUFA which showed similar levels in neutral and polar lipids.

\section{DISCUSSION}

\section{Analysis of the 2008 summer mortality}

This paper reports a study conducted during an exceptional mass mortality event in 1-yr-old oysters cultivated in the Mediterranean Thau lagoon. Summer mortality was recorded in most oyster production areas in France in 2008, representing the most important crisis of the national oyster industry since the introduction of Crassostrea gigas in the early 1970s. In the Thau lagoon, this exceptional mortality event occurred in 2 phases: between 13 May and 10 June, when seawater temperature first exceeded $19^{\circ} \mathrm{C}$, and between 24 June and 9 July.

In several respects, the observed mortality events fit with the interaction model recently proposed to explain the summer mortality of the Pacific oyster (Samain \& McCombie 2008). Indeed, the 2008 mortality event severely affected 1-yr-old oysters, whereas 2 -yr-old animals remained much less affected. The lower mortality in 2-yr-old animals could be due to size, age or stock differences. Although speculative, weight-specific aerobic energy expenditures are generally higher in small oysters than in larger 2-yr-old animals (Koehn 1989, Abele et al. 2009), which probably renders them more sensitive to the mortality. The lower mortality in 2-yr-old oysters is unlikely to have resulted from the animals having been exposed to the causal agents during the previous year as they were reared in Brittany where no mortality was reported in 2007.

Furthermore, mortality episodes occurred during the spawning season when seawater temperature exceeded $19^{\circ} \mathrm{C}$ and followed marked increases in seawater temperature as reported in Samain \& McCombie (2008). Before the second mortality event, a sharp decrease in sugar concentration occurred and accumulation of reserve lipids was arrested in the oysters, suggesting energy reserve levels typical of the known summer mortality phenomenon (Soletchnik et al. 1997, 2006, Berthelin et al. 2000, Delaporte et al. 2006, 2007, Samain \& McCombie 2008). 
The examination of oysters during summer mortalities in the past has indicated the presence of pathogenic agents: several Vibrio sp. bacteria and the herpes virus OsHV-I (Renault et al. 1994, Lacoste et al. 2001, Renault \& Novoa 2004, Garnier et al. 2007, Sauvage et al. 2009). In our study, dead 1-yr-old oys- ters sampled on 10 June 2008 were screened for OsHV-1 virus using real-time PCR (Pepin et al. 2008) and showed a significant viral load $\left(10^{5}\right.$ to $10^{8}$ viral DNA $\mathrm{mg}^{-1}$ tissue), suggesting that OsHV-1 played a significant role in this mortality (Sauvage et al. 2009, J.-F. Pepin pers. comm.).
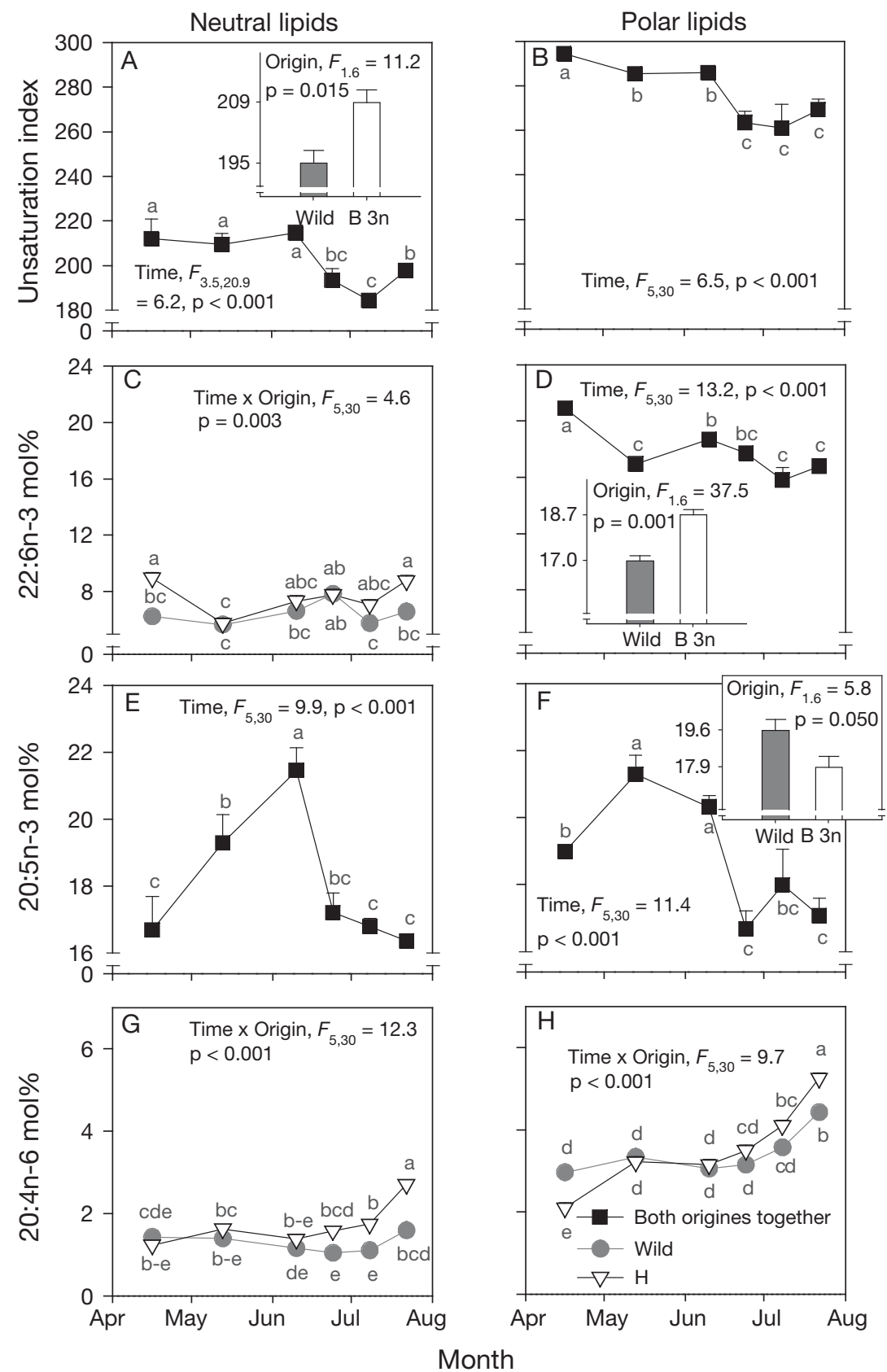

Fig. 7. Crassostrea gigas. 1-yr-old oysters. (A, B) unsaturation index and relative concentrations of (C, D) 22:6n-3, (E, F) 20:5n-3, and $(\mathrm{G}, \mathrm{H})$ 20:4n-6 expressed as mol\% of total fatty acid in neutral (left) and polar lipids (right) of oysters as a function of time and origin (when significant). Oysters were wild-collected from the field or were triploids produced in a commercial hatchery. Letters indicate significant differences. Repeated measures ANOVA conducted to assess whether there were differences among combinations of time and origin (df were corrected following Huyn-Feldt when necessary). (A, D, F) = main effect of the origin when factor did not interact with time. Data: mean \pm SE between ropes $(n=4)$. Each rope included 4 pearl nets from which 1 or 2 oysters were sampled and pooled together 
The mortality events that occurred in the Thau lagoon also show clear deviations from the interaction model of oyster summer mortality, in which reproductive effort is pivotal (Delaporte et al. 2006, 2007, Gagnaire et al. 2006, Samain \& McCombie 2008, Li et al. 2009). Indeed, triploid oysters usually show higher resistance to summer mortality than diploid animals, reflecting differences in reproductive effort (Normand et al. 2008) and immunological parameters (Gagnaire et al. 2006). In our study, mortality in sexually active diploid oysters was similar to that of triploid animals, which showed a visibly limited allocation to reproduction compared with diploids. Similar results were reported in the USA (Cheney et al. 2000). These contrasting findings suggest that the reproductive effort of oysters is not a necessary condition for triggering the mortality: low energy reserve levels in oysters, environmental conditions and pathogens may be enough.

The interaction model of summer mortality occurring along the English Channel and Atlantic coasts predicts that excessive rainfall and nutrient inputs can lead to increasing levels of primary productivity that cause degradation of benthic habitats by decreasing dissolved oxygen level and redox conditions in sediments and bottom waters and enhance reproductive effort at the expense of the oyster defence system, thus favouring mortality (Samain \& McCombie 2008). In contrast, the exceptional mortality in the Thau lagoon coincided with a strong deficit in phytoplankton during the spring and summer of 2008 compared with the 19972006 period where no mortality was reported, and we did not detect any period of marked hypoxia before or during the oyster mortality. Indeed, algal blooms, which usually occur in June and late in the summer in the Thau lagoon, were rather low or absent in 2008.

Soletchnik et al. (2006) noticed that summer mortality sometimes coincided with an unusual absence of phytoplankton blooms during the energetically demanding period of reproduction in oysters. A modelling study suggests that at the end of spring, while oysters have maximal metabolic needs and minimal reserves, the food supply from the environment is crucial and any deficit will cause an energy deficiency (Pouvreau et al. 2006). Therefore, the low sugar concentration in 1-yr-old oysters, which was irrespective of their reproductive stage and the mortality that followed, probably reflects inadequate food supply from the environment. In support of this hypothesis, shell length of oysters remained constant during the periods when mortality occurred, suggesting that energetic restrictions may have limited oyster growth. Furthermore, sexual maturation in the 1-yr-old oysters slowed after reaching Stage 2 at the end of May, which also supports the idea of an energetic limitation in this ageclass.
Although several studies showed that trophic mismatch in the marine environment is increasing due to global climate change (e. g. Edwards \& Richardson 2004, Kirby et al. 2008), low phytoplankton level in the Thau lagoon in 2008 probably resulted from a shortterm deficit in rainfall during the preceding winter, which exacerbated an on going long-term reduction in nutrient inputs from the catchments (Collos et al. 2009).

\section{Mortality and fatty acid dynamics in oysters}

Fatty acid analyses suggest that there was no apparent deficiency in the long-chain PUFA 22:6n3, 20:5n-3 and 20:4n-6, which are essential for sustaining growth and improving survival in several bivalve species (Langdon \& Waldock 1981, Delaunay et al. 1993). Neutral lipids of oysters were dominated by the diatom marker 20:5n-3, rather than the dinoflagellate marker 22:6n-3 (Dalsgaard et al. 2003), thus indicating that oysters fed on a diatom-based diet. This result agrees with the taxonomic description of the phytoplanktonic community of Thau Lagoon.

Interestingly, the contribution of bacterial fatty acids to the neutral lipids of the oysters increased markedly at the expense of 20:5n-3 just before the second mortality event. This increase in bacterial fatty acids probably reflects an enhancement of the microbial loop or decomposition processes (Dalsgaard et al. 2003). Indeed, bacterial production can represent a significant proportion of organic carbon in aquatic food webs, particularly in oligotrophic systems (Legendre \& Rivkin 2005). Furthermore, fatty acids of bacterial origin can be transferred to higher trophic levels without modification (Ederington et al. 1995). In our study, bacterial fatty acids accounted for 2 to $4 \%$ of the neutral lipids of oysters. Similarly, these fatty acids represented $\sim 3.1 \%$ of the neutral lipids in 3-yr-old oysters sampled during the reproductive period (Soudant et al. 1999). More broadly, benthic invertebrates living in oligotrophic temperate areas show moderate levels of bacterial fatty acids, ranging from 3 to $5 \%$ of total fatty acids (Richoux \& Froneman 2008). Therefore, levels of bacterial fatty acids in oysters seemed normal when compared with levels found by previous studies. However, their increase before the second mortality event may reflect a short-term environmental degradation that might have contributed to triggering mortality.

The unsaturation index of neutral and polar lipids in the oysters decreased markedly before the second mortality event, reflecting changes in the long-chain PUFA 20:5n-3. This change in oyster fatty acid composition, which occurred during the spawning period, may reflect the release of PUFA-rich gametes. There is 
little support for this hypothesis, however, as unsaturation index and 20:5n-3 in sexually active diploid oysters was similar to that of triploid animals, which showed a limited allocation to reproduction compared with diploids.

We therefore hypothesized that variation in fatty acid profile in oysters reflected that of their food (see previous paragraph). However, given that polar lipids are generally higher in PUFA and more resistant to dietary changes than neutral lipids (Sargent et al. 2002), a change in dietary fatty acid would have first impacted neutral lipids, followed by polar lipids. In our study, the decrease in unsaturation index and longchain PUFA was similar and/or earlier (i.e. 20:5n-3) in polar lipids compared with neutral lipids. Therefore, although variation in the fatty acid profile of oysters may reflect changes in dietary fatty acids, this was clearly not the only reason.

Alternatively, it is generally accepted that decreasing unsaturation index and long-chain PUFA in oysters reflect acclimatization to increasing seawater temperature. Indeed, the thermal sensitivity of membrane processes is due to the strong effect of temperature on the physical properties of membrane lipids, which in turn have a major influence on associated proteins (Hochachka \& Somero 2002). An increase in temperature usually enhances membrane fluidity, which can lead to membrane dysfunction. Ectothermic animals compensate the effect of increasing temperature on membrane fluidity by reducing the unsaturation index of fatty acids in their membranes, a process known as homeoviscous adaptation (Hazel 1995). Several bivalve species have been seen to change their membrane lipids in response to temperature in a direction consistent with homeoviscous adaptation (Hall et al. 2002, Pernet et al. 2008 and references therein).

However, this hypothesis should be tempered by the fact that the remodelling of membrane fatty acids occurred between 10 June and 24 June while seawater temperature was stable at 19 to $21^{\circ} \mathrm{C}$ for $\sim 1$ mo. Changes in membrane fatty acids may compensate for the increase in temperature that occurred between 18 March and 8 May. Indeed, the increase in unsaturation index of lipids in 1-yr-old hard clams is viewed as a long term response to declining temperature, whereas other compensatory mechanisms occur on the short term (Pernet et al. 2006). In contrast, eastern oysters exposed to increasing temperatures from 12 to $25^{\circ} \mathrm{C}$ show a decrease in unsaturation index compared to control group maintained at $12^{\circ} \mathrm{C}$ after only $20 \mathrm{~d}$ (Pernet et al. 2007a). Another intriguing result in the present study is that unsaturation index decreased not only in polar lipids, but also in neutral lipids. Because neutral lipids are not linked to membrane function, they seem less likely than polar lipids to change with increasing temperature. Therefore, the marked decrease in unsaturation index and 20:5n-3 before the second mortality event does not necessarily represent the acclimatization of oysters to increasing temperature.

Another hypothesis is that decreasing unsaturation index and long-chain PUFA reflect oxidative damage in oysters. Reactive oxygen species (ROS) are ions or very small molecules that include oxygen ions, free radicals, and peroxides (inorganic or organic). They are highly reactive due to the presence of unpaired valence shell electrons. ROS form as a natural by-product of the normal oxygen metabolism. These oxygen derivatives are normally kept under control by antioxidant defence systems to limit tissue peroxidation. However, during times of environmental stress (Abele \& Puntarulo 2004) or exposure to pathogens (Lambert et al. 2007), ROS levels can increase dramatically, resulting in significant damage to cell structures. Oysters from families selected to be susceptible to summer mortalities exhibit a higher level of reactive oxygen species compared with that of resistant animals, probably reflecting reduced antioxidant capacities in sensitive oysters (Delaporte et al. 2007, Lambert et al. 2007). Since the susceptibility of fatty acid to peroxidative damage increases with the degree of unsaturation, the observed decrease in 20:5n-3 and unsaturation index in lipids of oysters before the second mortality event may reveal an enhanced production of ROS that preferentially attack long-chain PUFA.

Arachidonic acid increased markedly in the polar lipids of oysters from 24 June onward. Similarly, 20:4n-6 increased markedly in the polar lipids of blue mussels and, to a lower extent, of eastern oysters, during the passage from overwintering $\left(0\right.$ to $\left.9^{\circ} \mathrm{C}\right)$ to summer temperatures $\left(20^{\circ} \mathrm{C}\right.$, Pernet et al. 2007b). These authors suggest that levels of this $\mathrm{C}_{20}$ PUFA may have increased during the temperature rise through the stimulation of immune function due to increased bacterial loads in the seawater.

\section{Fatty acid signatures in different groups of oysters}

Intriguingly, wild-collected and hatchery-bred oysters maintained in the same environment for several months exhibited persistent differences in their levels of long-chain PUFA such as 22:6n-3 and 20:5n-3, as previously reported in eastern oysters Crassostrea virginica (Pernet et al. 2008). Although the biosynthetic production of these PUFA is rather low or absent, meaning that the fatty acid composition of lipids in bivalve tissues generally reflects that of their diet, several studies have shown that fatty acid composition in bivalve membrane lipids is regulated by selective in- 
corporation or elimination of fatty acids (e. g. Delaunay et al. 1993). Therefore, it was suggested that persistence of dissimilarities in levels of PUFA among groups of oysters kept in the same environment reveals differences in their capacity for selective incorporation of dietary PUFA into membrane lipids (Pernet et al. 2008).

Differences in fatty acids between wild-collected and hatchery-bred oysters may reflect differences in their genetic characteristics, as previously observed in eastern oysters (Pernet et al. 2008). Taking a broader outlook, genetic differences in the metabolism of longchain $\mathrm{C}_{20}$ and $\mathrm{C}_{22}$ PUFA have been reported in domesticated mammals, and may also reflect genetic differences in fatty acid metabolism (De Smet et al. 2004). It should be noted, however, that domestication and selective breeding are still very limited for the Pacific oyster in France (Boudry 2009) and are therefore unlikely to explain our result. Additionally, any genetically-based differences in our study would be confounded with differences in ploidy level and differences in rearing conditions before the experiment.

Although wild-collected and hatchery-bred oysters had suffered similar levels of mortality by the end of the study $(\sim 85 \%)$, wild-collected oysters showed earlier mortality than hatchery-bred animals, therefore reflecting a greater susceptibility to the mass mortality phenomenon. Differences in long-chain PUFA, which are involved in thermal adaptation and metabolism (Hazel 1995, Hulbert \& Else 1999), may be a sign of difference in resistance to mass mortality.

The initial level of 20:4n-6 in the polar lipids of wildcollected oysters was markedly higher $(3.0 \%)$ than that of hatchery-bred animals for which 20:4n-6 was only $2.1 \%$, probably indicating a higher level of stress in the wild-collected oysters. This coincides very well with the fact that these wild-collected oysters rapidly suffered heavy losses on 13 May whereas hatchery-bred oysters remained free of mortality at this point. It is also noteworthy that 20:4n-6 increased to $3.2 \%$ in hatchery-bred oysters by 13 May, as observed in wild-collected animals. Again, this increase in 20:4n-6 coincides with the start of the mortality in the hatchery-bred oysters. Therefore, mortality started when 20:4n-6 increased to a threshold value of $\sim 3 \%$ in the polar lipids, suggesting that this PUFA may be a useful indicator of summer mortality risk in oysters. In support of this idea, mortality events in sea scallop larvae coincide with marked enrichments in 20:4n-6 (Pernet et al. 2005).

\section{Concluding remarks}

The 2008 mortality event in Thau coincided with a $\sim 1.5^{\circ} \mathrm{C}$ increase in seawater temperature in January and February 2008 compared with temperatures recorded during the 1997-2006 period where no mortality was reported in the area. In 2008, oysters throughout France, including those transferred to the Mediterranean for our study, were exposed to similar exceptional conditions during their early lives. Little information is available concerning the effect of overwintering temperature on oyster mortality. Although metabolic rates of bivalves increase with seawater temperature (Bayne 1983), an increase of $1.5^{\circ} \mathrm{C}$ in overwintering temperature may have little impact on the energetic balance in oysters. Indeed, physiological measurements made at 4 to $5^{\circ} \mathrm{C}$ and 9 to $10^{\circ} \mathrm{C}$ in Crassostrea gigas and $C$. virginica reveal no significant change in clearance and respiration rates (Bougrier et al. 1995, Pernet et al. 2007b). However, an increase in overwintering temperature may impact reproductive processes. In temperate areas, C. gigas exhibits a seasonal reproductive cycle related to temperature (Mann 1979, Normand et al. 2008). More particularly, gonia proliferation is triggered by low temperatures between 8 to $11^{\circ} \mathrm{C}$ (Fabioux et al. 2004, 2005). Oysters exposed to accelerated temperature and photoperiod cycles undergo gonia proliferation while unspawned gametes have not yet been resorbed (Fabioux et al. 2005). Finally, an increase in overwintering temperature relaxes restrictions on pathogen life cycles and therefore increases pathogen development rates, transmission and the number of generations per year (Harvell et al. 2002). Therefore, a higher winter temperature in 2008 may have favoured the spring revival of pathogenic organisms involved in summer mortalities such as Vibrio bacteria and the herpes virus OsHV-I.

Mortality occurred when seawater temperature was $>19^{\circ} \mathrm{C}$ during the reproductive season when energetic reserves of oysters were at their lowest, which agrees well with the interaction model of summer mortality in Pacific oyster (Samain \& McCombie 2008). However, energy reserve levels and mortality in oysters seemed to be independent of reproductive effort, and most likely reflected an unusual deficit in phytoplankton that resulted from a rainfall deficit the preceding winter. This situation seems specific to the Mediterranean area. Indeed, during the summer 2008, oysters living on the Channel and Atlantic coasts showed early reproductive maturation and elevated reproductive effort, reflecting elevated phytoplankton concentrations and nutrient inputs from catchments due to heavy rainfalls during the preceding winter-spring (Anonymous 2008). In both situations, mortality in young oysters was remarkably high.

For the first time, we show that mortality patterns coincide with changes in fatty acid composition of neutral (reserve) and polar (membrane) lipids, indicating that diet has changed, that oysters acclimatize to increasing temperature, or that they face oxidative 
damage due to an enhanced production of reactive oxygen species often associated with stressful situations. Additionally, wild-collected and hatchery-bred oysters, which exhibit different mortality patterns, showed persistent differences in their membrane PUFA, despite the fact that they were reared in the same environment. Therefore, differences in longchain PUFA in oysters may indicate a difference in resistance to mass mortality.

Acknowledgements. The authors are grateful to the staff of the Ifremer Laboratoire Environnement Ressources en Languedoc-Roussillon and Cepralmar for their help with fieldwork. The authors also wish thank the staff involved in environmental and shellfish networks, and those people who actively participated in Ifremer's mortality research forum, for stimulating discussions. Finally, the authors express their gratitude to $\mathrm{H}$. McCombie for revising the English version of this manuscript and to J.-F. Samain for critical discussions.

\section{LITERATURE CITED}

Abele D, Puntarulo S (2004) Formation of reactive species and induction of antioxidant defence systems in polar and temperate marine invertebrates and fish. Comp Biochem Physiol Physiol 138:405-415

Abele D, Brey T, Philipp E (2009) Bivalve models of aging and the determination of molluscan lifespans. Exp Gerontol 44:307-315

Aminot A, Kérouel R (2004) Hydrologie des écosystèmes marins: paramètres et analyses. Editions de Ifremer/Quæ, Versailles

Anonymous (2008) Mortalités d'huîtres 2008: les causes environnementales aggravantes. Document de synthèse. Ifremer

Bayne BL (1983) Physiological ecology of marine molluscan larvae. In: Verdonk $\mathrm{NH}$ (ed) The mollusca. Academic press, New York, p 299-343

Berthelin C, Kellner K, Mathieu M (2000) Storage metabolism in the Pacific oyster (Crassostrea gigas) in relation to summer mortalities and reproductive cycle (West Coast of France). Comp Biochem Physiol B Biochem Mol Biol 125: 359-369

Boudry P (2009) Genetic variation and selective breeding in hatchery-propagated molluscan shellfish. In: Burnell G, Geoff A (eds) New technologies in aquaculture: improving production efficiency, quality and environmental management. Woodhead Publishing Limited, Cambridge, p 87-108

Bougrier S, Geairon P, Deslouspaoli JM, Bacher C, Jonquieres G (1995) Allometric relationships and effects of temperature on clearance and oxygen-consumption rates of Crassostrea gigas (Thunberg). Aquaculture 134:143-154

Budge SM, Parrish CC (1998) Lipid biogeochemistry of plankton, settling matter and sediments in Trinity Bay, Newfoundland. II. Fatty acids. Org Geochem 29:1547-1559

Chapelle A, Lazure P, Souchu P (2001) Modelling anoxia in the Thau lagoon (France). Oceanol Acta 24:S87-S97

Cheney DP, MacDonald BF, Elston RA (2000) Summer mortality of Pacific oysters, Crassostrea gigas (Thunberg): initial findings on multiple environmental stressors in Puget Sound, Washington, 1998. J Shellfish Res 19:353-359

Collos Y, Bec B, Jauzein C, Abadie E and others (2009) Oligo- trophication and emergence of picocyanobacteria and a toxic dinoflagellate in Thau lagoon, southern France. J Sea Res 61:68-75

Dalsgaard J, St. John M, Kattner G, Muller-Navarra D, Hagen W (2003) Fatty acid trophic markers in the pelagic marine environment. Adv Mar Biol 46:225-340

> De Smet S, Raes K, Demeyer D (2004) Meat fatty acid composition as affected by fatness and genetic factors: a review. Anim Res 53:81-98

Delaporte M, Soudant P, Moal J, Lambert C and others (2003) Effect of a mono-specific algal diet on immune functions in two bivalve species - Crassostrea gigas and Ruditapes philippinarum. J Exp Biol 206:3053-3064

> Delaporte M, Soudant P, Lambert C, Moal J, Pouvreau S, Samain JF (2006) Impact of food availability on energy storage and defense related hemocyte parameters of the Pacific oyster Crassostrea gigas during an experimental reproductive cycle. Aquaculture 254:571-582

Delaporte M, Soudant P, Lambert C, Jegaden M and others (2007) Characterisation of physiological and immunological differences between Pacific oysters (Crassostrea gigas) genetically selected for high or low survival to summer mortalities and fed different rations under controlled conditions. J Exp Mar Biol Ecol 353:45-57

> Delaunay F, Marty Y, Moal J, Samain JF (1993) The effect of monospecific algal diets on growth and fatty acid composition of Pecten maximus (L.) larvae. J Exp Mar Biol Ecol 173:163-179

> DuBois M, Gilles KA, Hamilton JK, Rebers PA, Smith F (1956) Colorimetric method for determination of sugars and related substances. Anal Chem 28:350-356

Ederington MC, McManus GB, Harvey HR (1995) Trophic transfer of fatty-acids, sterols, and a triterpenoid alcohol between bacteria, a ciliate, and the copepod Acartia tonsa. Limnol Oceanogr 40:860-867

- Edwards M, Richardson AJ (2004) Impact of climate change on marine pelagic phenology and trophic mismatch. Nature 430:881-884

> Fabioux C, Huvet A, Lelong C, Robert R and others (2004) Oyster vasa-like gene as a marker of the germline cell development in Crassostrea gigas. Biochem Biophys Res Commun 320:592-598

Fabioux C, Huvet A, Le Souchu P, Le Pennec M, Pouvreau S (2005) Temperature and photoperiod drive Crassostrea gigas reproductive internal clock. Aquaculture 250:458-470

Friedman CS, Estes RM, Stokes NA, Burge CA and others (2005) Herpes virus in juvenile Pacific oysters Crassostrea gigas from Tomales Bay, California, coincides with summer mortality episodes. Dis Aquat Org 63:33-41

Gagnaire B, Soletchnik P, Madec P, Geairon P, Le Moine O, Renault T (2006) Diploid and triploid Pacific oysters, Crassostrea gigas (Thunberg), reared at two heights above sediment in Marennes-Oleron Basin, France: difference in mortality, sexual maturation and hemocyte parameters. Aquaculture 254:606-616

Gailhard I, Gros P, Durbec JP, Beliaeff B, Belin C, Nezan E, Lassus P (2002) Variability patterns of microphytoplankton communities along the French coasts. Mar Ecol Prog Ser 242:39-50

Gangnery A, Chabirand JM, Lagarde F, Gall PL, Oheix J, Bacher C, Buestel D (2003) Growth model of the Pacific oyster, Crassostrea gigas, cultured in Thau Lagoon (Méditerranée, France). Aquaculture 215:267-290

Garnier M, Labreuche Y, Garcia C, Robert A, Nicolas JL (2007) Evidence for the involvement of pathogenic bacteria in summer mortalities of the Pacific oyster Crassostrea gigas. Microb Ecol 53:187-196 
Guarini JM, Gros P, Blanchard G, Richard P, Fillon A (2004) Benthic contribution to pelagic microalgal communities in two semi-enclosed, European-type littoral ecosystems (Marennes-Oléron Bay and Aiguillon Bay, France). J Sea Res 52:241-258

Hall JM, Parrish CC, Thompson RJ (2002) Eicosapentaenoic acid regulates scallop (Placopecten magellanicus) membrane fluidity in response to cold. Biol Bull 202:201-203

- Harvell CD, Kim K, Burkholder JM, Colwell RR and others (1999) Emerging marine diseases-climate links and anthropogenic factors. Science 285:1505-1510

- Harvell CD, Mitchell CE, Ward JR, Altizer S, Dobson AP, Ostfeld RS, Samuel MD (2002) Climate warming and disease risks for terrestrial and marine biota. Science 296: $2158-2162$

> Hayes ML, Bonaventura J, Mitchell TP, Prospero JM, Shinn EA, Van Dolah F, Barber RT (2001) How are climate and marine biological outbreaks functionally linked? Hydrobiologia 460:213-220

Hazel JR (1995) Thermal adaptation in biological membranes: Is homeoviscous adaptation the explanation? Annu Rev Physiol 57:19-42

Hochachka PM, Somero GN (2002) Biochemical adaptation. Princeton University Press, Oxford

Hulbert AJ, Else PL (1999) Membranes as possible pacemakers of metabolism. J Theor Biol 199:257-274

Hulbert AJ, Pamplona R, Buffenstein R, Buttemer WA (2007) Life and death: metabolic rate, membrane composition, and life span of animals. Physiol Rev 87:1175-1213

Kemp WM, Boynton WR, Adolf JE, Boesch DF and others (2005) Eutrophication of Chesapeake Bay: historical trends and ecological interactions. Mar Ecol Prog Ser 303: $1-29$

Kirby RR, Beaugrand G, Lindley JA (2008) Climate-induced effects on the meroplankton and the benthic-pelagic ecology of the North Sea. Limnol Oceanogr 53:1805-1815

> Koehn RK (1989) Towards a physiological and genetical understanding of the energetics of the stress response. Biol J Linn Soc 37:157-171

Lacoste A, Jalabert F, Malham S, Cueff A and others (2001) A Vibrio splendidus strain is associated with summer mortality of juvenile oysters Crassostrea gigas in the Bay of Morlaix (North Brittany, France). Dis Aquat Org 46:139-145

Lafferty KD, Porter JW, Ford SE (2004) Are diseases increasing in the ocean? Annu Rev Ecol Evol Syst 35:31-54

Lambert C, Soudant P, Degremont L, Delaporte M and others (2007) Hemocyte characteristics in families of oysters, Crassostrea gigas, selected for differential survival during summer and reared in three sites. Aquaculture 270: 276-288

Langdon CJ, Waldock MJ (1981) The effect of algal and artificial diets on the growth and fatty acid composition of Crassostrea gigas spat. J Mar Biol Assoc UK 61:431-448

Legendre L, Rivkin RB (2005) Integrating functional diversity, food web processes, and biogeochemical carbon fluxes into a conceptual approach for modeling the upper ocean in a high-CO2 world. J Geophys Res 110:C09S17 doi: 10.1029/2004JC002530

Li Y, Qin JG, Li X, Benkendorff K (2009) Monthly variation of condition index, energy reserves and antibacterial activity in Pacific oysters, Crassostrea gigas, in Stansbury (South Australia). Aquaculture 286:64-71

Lowry OH, Rosebrough NJ, Farr AL, Randall RJ (1951) Protein measurement with Folin reagent. J Biol Chem 193: 265-275

> Luna-González A, Romero-Geraldo Md J, Campa-Córdova Á Orduña-Rojas J, Valles-Jiménez R, Ruíz-Verdugo CA
(2008) Seasonal variations in the immunological and physiological parameters of the Pacific oyster Crassostrea gigas cultured in Bahia de Macapule (Sinaloa, Mexico). Aquacult Res 39:1488-1497

- Malham SK, Cotter E, O'Keeffe S, Lynch S and others (2009) Summer mortality of the Pacific oyster, Crassostrea gigas, in the Irish Sea: the influence of temperature and nutrients on health and survival. Aquaculture 287:128-138

Mann R (1979) Some biochemical and physiological aspects of growth and gametogenesis in Crassostrea gigas and Ostrea edulis grown at sustained elevated temperatures. J Mar Biol Assoc UK 59:95-110

> Marty Y, Delaunay F, Moal J, Samain JF (1992) Changes in the fatty acid composition of Pecten maximus (L.) during larval development. J Exp Mar Biol Ecol 163:221-234

- Metcalfe LD, Schmitz AA (1961) The rapid preparation of fatty acid esters for gas chromatographic analysis. Anal Chem 33:363-364

Mori K (1979) Effects of artificial eutrophication on the metabolism of the Japanese oyster Crassostrea gigas. Mar Biol 53:361-369

> Mydlarz LD, Jones LE, Harvell CD (2006) Innate immunity environmental drivers and disease ecology of marine and freshwater invertebrates. Annu Rev Ecol Evol Syst 37: 251-288

Normand J, Le Pennec M, Boudry P (2008) Comparative histological study of gametogenesis in diploid and triploid Pacific oysters (Crassostrea gigas) reared in an estuarine farming site in France during the 2003 heatwave. Aquaculture 282:124-129

Osada M, Nomura T (1989) Estrogen effect on the seasonal levels of catecholamines in the scallop Patinopecten yessoensis. Comp Biochem Physiol 93:349-353

Pepin JF, Riou A, Renault T (2008) Rapid and sensitive detection of ostreid herpesvirus 1 in oyster samples by real-time PCR. J Virol Methods 149:269-276

Perdue JA, Beattie JH, Chew KK (1981) Some relationships between gametogenic cycle and summer mortality phenomenon in the pacific oyster (Crassostre gigas) in Washington state. J Shellfish Res 1:9-16

$>$ Pernet F, Bricelj VM, Parrish CC (2005) Effect of varying dietary levels of w6 polyunsaturated fatty acids during the early ontogeny of the sea scallop, Placopecten magellanicus. J Exp Mar Biol Ecol 327:115-133

> Pernet F, Tremblay R, Gionet C, Landry T (2006) Lipid remodeling in wild and selectively bred hard clams at low temperatures in relation to genetic and physiological parameters. J Exp Biol 209:4663-4675

- Pernet F, Gauthier-Clerc S, Mayrand E (2007a) Change in lipid composition in Eastern oyster (Crassostrea virginica Gmelin) exposed to constant or fluctuating temperature regimes. Comp Biochem Physiol B Biochem Mol Biol 147: $557-565$

Pernet F, Tremblay R, Comeau L, Guderley H (2007b) Temperature adaptation in two bivalve species from different thermal habitat: energetic and remodeling of membrane lipids. J Exp Biol 210:2999-3014

Pernet F, Tremblay R, Redjah I, Sevigny JM, Gionet C (2008) Physiological and biochemical traits correlate with differences in growth rate and temperature adaptation among groups of the eastern oyster Crassostrea virginica. J Exp Biol 211:969-977

Pouvreau S, Bourles Y, Lefebvre S, Gangnery A, AlunnoBruscia M (2006) Application of a dynamic energy budget model to the Pacific oyster, Crassostrea gigas, reared under various environmental conditions. J Sea Res 56: 156-167 
Renault T, Novoa B (2004) Viruses infecting bivalve molluscs. Aquat Living Resour 17:397-409

Renault T, Ledeuff RM, Cochennec N, Maffart P (1994) Herpesviruses associated with mortalities among Pacific oyster, Crassostrea gigas, in France: comparative study. Rev Med Vet 145:735-742

Richoux NB, Froneman PW (2008) Trophic ecology of dominant zooplankton and macrofauna in a temperate, oligotrophic South African estuary: a fatty acid approach. Mar Ecol Prog Ser 357:121-137

Samain JF, McCombie H (2008) Summer mortality of Pacific oyster Crassostrea gigas: The Morest Project. Ifremer/ Quæ Editions, Versailles

Sargent JR, Tocher DR, Bell JG (2002) The lipids. In: Halver JE, Hardy RW (eds) Fish nutrition. Academic Press, Amsterdam, p 181-255

Sauvage C, Pépin JF, Lapègue S, Boudry P, Renault T (2009) Ostreid herpes virus 1 infection in families of the Pacific oyster, Crassostrea gigas, during a summer mortality outbreak: differences in viral DNA detection and quantification using real-time PCR. Virus Res 142:181-187

Smith WL, Murphy RC (2003) The eicosanoids: cyclooxygenase, lipoxygenase, and epoxygenase pathways. In: Vance DE, Vance JE (eds) Biochemistry of lipids, lipoproteins and membranes, Vol 36. Elsevier Science, Amsterdam, p 341-371

Soletchnik P, Razet D, Geairon P, Faury N, Goulletquer P

Editorial responsibility: Inna Sokolova,

Charlotte, North Carolina, USA
(1997) Ecophysiology of maturation and spawning in oyster (Crassostrea gigas): metabolic (respiration) and feeding (clearance and absorption rates) responses at different maturation stages. Aquat Living Resour 10:177-185

Soletchnik P, Faury N, Goulletquer P (2006) Seasonal changes in carbohydrate metabolism and its relationship with summer mortality of Pacific oyster Crassostrea gigas (Thunberg) in Marennes-Oléron bay (France). Aquaculture 252: 328-338

Soletchnik P, Ropert M, Mazurie J, Fleury PG, Le Coz F (2007) Relationships between oyster mortality patterns and environmental data from monitoring databases along the coasts of France. Aquaculture 271:384-400

Soudant P, Van RK, Marty Y, Moal J, Samain JF, Sorgeloos P (1999) Comparison of the lipid class and fatty acid composition between a reproductive cycle in nature and a standard hatchery conditioning of the Pacific oyster Crassostrea gigas. Comp Biochem Physiol B Biochem Mol Biol 123:209-222

Stanley D, Howard R (1998) The biology of prostaglandins and related eicosanoids in invertebrates: cellular, organismal and ecological actions. Am Zool 38:369-381

> Watermann BT, Herlyn M, Daehne B, Bergmann S, Meemken M, Kolodzey H (2008) Pathology and mass mortality of Pacific oysters, Crassostrea gigas (Thunberg), in 2005 at the East Frisian coast, Germany. J Fish Dis 31: $621-630$

Submitted: April 29, 2009; Accepted: November 9, 2009 Proofs received from author(s): February 11, 2010 